\title{
Acaciella angustissima (Mill.) Brit. \& Rose: Botanical Features, Distribution, Medicinal and Pharmacological Properties
}

\author{
Collen Musara* and Elizabeth Bosede Aladejana
}

\author{
Medicinal Plants and Economic Development (MPED) Research Centre, Department of Botany, University of \\ Fort Hare, Private Bag X1314, Alice 5700, South Africa
}

\begin{abstract}
Acaciella angustissima (Mill.) Brit. \& Rose is a multipurpose deciduous thornless shrub or small tree that belongs to the family Fabaceae and subfamily Mimosoideae. This study aimed to explore A. angustissima, a leguminous shrub with medicinal, ecological and industrial potential. A mixed-method approach, which included consolidating quantitative and qualitative research, was utilized to put together the review with the main focus being on sub-Saharan Africa. However, case studies and literature from South Africa were also utilized. A. angustissima is a good source of phenolic compounds. It is used to relieve painful toothache, rheumatism, skin lesions, bloody diarrhea and mucoid diarrhea. It also displays a mild antimicrobial effect and has the ability to inhibit growth in malignant tumors. The study acknowledged Acaciella angustissima as an important agroforestry tree species that improve the quality of life of resource-poor farmers, reducing poverty and promoting sustainability of the natural resources base and economic growth
\end{abstract}

Keywords: Acaciella angustissima, medicinal, economic importance, sub-Saharan Africa.

\section{INTRODUCTION}

Acaciella angustissima (Mill.) Brit. \& Rose belongs to the genus Acacia Miller, Fabaceae family and Mimosoidea subfamily [1]. The deciduous shrub is composed of species with high morphological variability, extensive synonymy and its high invasiveness potential [1-3]. Despite its invasiveness, $A$. angustissima has been adopted and is being effectively promoted in various nations, primarily in Africa [2]. A. angustissima is a woody perennial plant composed of six varieties which are $A$. angustissima var. angustissima (Mill.)Britton\& Rose; $A$. angustissima var. chisosianalsely; $A$. angustissima var. hirta (Nutt.) B.L. Rob.; A. angustissima var. shrevei (Britton \& Rose) Isely; $A$. angustissima var. suffrutescens (Rose) Isely and $A$. angustissima var. texensis (Torr. \& A. Gray) Isely [1]. The chromosome number for $A$. angustissima is reported as $2 n=26$ [1]. Pollination within the shrub is reported to be carried out by the honey bee which is regarded as the main pollen vector for the species [4]. Retaining the Acacia name has caused significant controversy in the field; however, most taxonomists across the globe have resolved to accept the renaming of the genus as Acaciella [1]. Therefore, the name Acaciella angustissima (Mill.) Brit. $\&$ Rose has been adopted in this review since it is the widely accepted name.

\footnotetext{
*Address correspondence to this author at the Medicinal Plants and Economic Development (MPED) Research Centre, Department of Botany, University of Fort Hare, Private Bag X1314, Alice 5700, South Africa;

E-mail: collinmusara@gmail.com
}

ISSN: 2223-3806 / E-ISSN: 1927-5951/20
Health issues in many southern African countries are the result of poor and limited health facilities, limited access to modern medical facilities, lack of drugs and if available they are exorbitantly priced [5]. These factors among others are a primary constraint and supplementation with local herbs play an important role in alleviating the poor health in these countries [6]. Many rural communities mainly rely on traditional medicines (herbs) since modern-day drugs are inaccessible or unreasonably expensive for most of the poor people [7]. With the current trend where most communities are clinging to traditional approaches, researchers have identified Acaciella angustissima as an economically important herbal plant [8]. Focusing, on its multipurpose roles, $A$. angustissima can develop local rural households and community's livelihoods. A detailed appraisal of the existing knowledge and literature on $A$. anguistissima morphology, distribution, medicinal and pharmacological properties are discussed in this article.

\section{METHODOLOGY OF THE REVIEW}

The literature search for this review was conducted from both scientific research articles and from grey literature using the terms "Acaciella angustissima", "Multipurpose trees", "Soil fertility", "Traditional medicines" and "Biomass transfer." Scientific literature was accessed from the following databases Google scholar, publishing sites such as Elsevier, JStor, Scopus, Science Direct, Cab Direct and BioMed Central (BMC) and PubMed. While the rest of the literature came from conference papers, books, theses, 
websites and government gazettes. While the review has a particular focus on sub-Saharan Africa; literature and case studies from other regions are also considered to assess the uses of the species. The review of the literature followed a mixed-method review approach, which included combining quantitative and qualitative data.

\section{Botanical Description}

The multipurpose tree develops as a thornless bush or small tree ranging between 2-7 $\mathrm{m}$ tall with a single brief trunk and is easy to prune as compared to other Acacias [9]. The tree exhibits variations in the pubescence, size and venation of the leaflets and as well as the size of the head and flowers that it displays $[9,10]$. A. angustissima leaves are mostly asymmetric ranging between $10-25 \mathrm{~cm}$ in length, with $10-20$ sets of pinnae and leaflets without optional venation as shown in Figure 1 [10]. Its inflorescences are ellipsoidal with whitish heads $1-1.5 \mathrm{~cm}$ in diameter, turning pinkish to gloomy orange when dried [10]. Flowers are protandrous [4], the pod is oblong, 3-6 cm long and 6-9 $\mathrm{mm}$ wide, and are at first green, turning coffee-brown as they age [10]. A. angustissima at high altitudes produce many seeds [2, 11], whose seed weight ranges between 90,000-100,000 seeds $/ \mathrm{kg}$. Apart from this, it has been observed to be drought-tolerant, largely due to its well-developed taproot [11].

\section{Distribution and Habitats}

A. angustissima, a member of the legume family, originated in Belice, Central America, is found in tropical and subtropical climates [1]. The species has a broad geographical range and it is native to North America but is also found in other parts of America [1]. Outside of the American subcontinent, it is also found in parts of Africa, Asia, Oceania and the Caribbean [1]. $A$. angustissima is the most broadly disseminated of the neo-tropical Acacia species, happening from Colombia north through Mexico [8].

The shrub tree is very versatile and tolerant to different types of soils, found on dry soils on slopes, savannahs, rough outcrops, meadows, open shrublands and well-drained soils [12]. A. angustissima can tolerate different climatic conditions in various ecosystems and in its native range, it grows in freedraining, infertile and acidic soils, with a yearly precipitation average of $400-3000 \mathrm{~mm}$, with temperatures ranging between $5{ }^{\circ} \mathrm{C}$ and $30{ }^{\circ} \mathrm{C}$ and it withstands cold climatic conditions [3, 13]. $A$. angustissima has a rapid growth rate, drought-tolerant and is highly productive in favourable, seasonally dry environments [3]. The shrub tree does not have thorns and thus, easy to prune and it establishes fast and produces up to $12.4 \mathrm{t} / \mathrm{ha}$ of biomass [14].

\section{Economic Importance}

Most studies on the economic importance of $A$. angustissima commenced in Australia, Indonesia, Papua New Guinea and Hawaii over the past 20-30 years [8, 13]. International Centre for Research in Agroforestry (ICRAF) has promoted $A$. angustissima use in Africa and most of the planting has been done and has been highly desirable for agroforestry [8, 15]. $A$. angustissima is shrub plant species with ecological, medical and industrial potential, hence can be used in a variety of applications such as in medicines, as green manure for soil regeneration, enhancement of the agricultural output and as fodder [3, 16, 17]. Correspondingly, the leguminous fodder trees have the ability to fix nitrogen and hence, have a higher potential for adoption compared to herbaceous legumes $[10,18$, 19].

\section{Medicinal Uses and Pharmacological Properties}

In Mexico, $A$. angustissima is used as herbal medicine to cures tooth-ache, rheumatism, arthritis, skin lesions, digestive tract problems, bloody diarrhea and mucoid diarrhoea $[20,21]$. The study of FeregrinoPérez et al. [21] has shown that the methanol extracts of $A$. angustissima are a good source of phenolic compounds, which are effective in preventing a plethora of diseases because they possess biological activities such as antidiabetic, antioxidants, anticancer, antimutagenic, and anti-inflammatory [20-22]. Studies have shown that $A$. angustissima possesses a mild inhibitory effect on Bacillus subtilis, Escherichia coli, Klebsiella pneumoniae, Candida albicans and Staphylococcus aureus; and also has a strong inhibitory effect on the growth of malignant tumors [20, 23]. In Mexico, it has also been reported to contain anticancer properties [24], and is used to treat gastrointestinal inflammation [25]. It is more sustainable exploiting phenolic-containing extracts from pods than the traditional bark since the extracts display antibacterial, antifungal and antiviral activities that may well be essential in agriculture [21].

Rodríguez-Méndez et al. [26] investigated the antidiabetic potential of the oral administration of methanol extract of $A$. angustissima on streptozotocininduced diabetic rats. The study revealed that at the concentration of $100 \mathrm{mg} / \mathrm{Kg}$ bwt, a significant reduction 


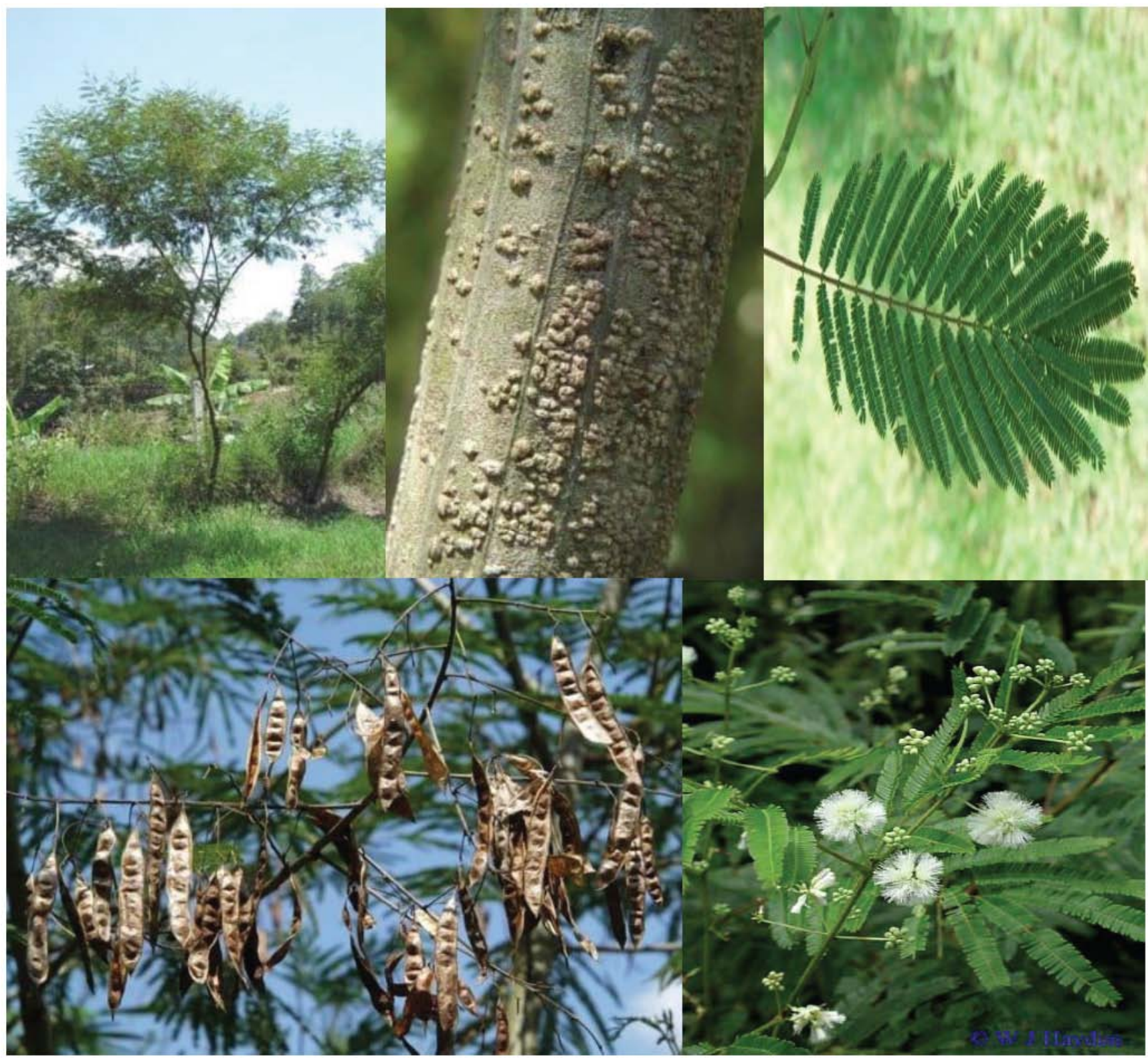

Figure 1: Acaciella angustissima (a) Tree, (b) Bark, (c) Leaf, (d) Seed, (e) Flower.

Source: Reid et al., [49].

in blood glucose levels (146.2 $\mathrm{mg} / \mathrm{dL})$, an increase in serum insulin concentration $(18.1 \mathrm{U} / \mathrm{mL})$, a reduction in lipid levels, and an improvement in the parameters of kidney damage. The improvements observed could be a result of the presence of bioactive compounds (phenolic compounds) in the plant. Furthermore, there was no glucose uptake activity in the adipocyte assay. The extract also exhibited a potential for the complementary treatment of diabetes and its complications probably due to the presence of protocatechuic acid. Thus, the plant displays antidiabetic activity by decreasing the levels of glucose, insulin, and improved physiological parameters, hypolipidemic effect, oxidative stress and renal damage in diabetic rats [26]. The study of Alonso-herrada et al.
[27] has shown that the methanol extracts of callus of $A$. angustissima are rich in phenolic compounds (gallic acid, catechin and rutin) which are usually products of defence against pathogen attack or in response to a stressful environment.

Vargas-Hernández et al. [28] investigated the methanolic extracts of $A$. angustissima pods for its antioxidant activity using1,1-diphenyl2-picrylhydrazyl (DPPH), 2,2-azinobis-3 ethylbenzothiazoline-6-sulfonic acid (ABTS), ferric reducing antioxidant power (FRAP); antimutagenic activity using Kado Micro-suspension assay; and antimicrobial activity using the in vitro antimicrobial assay. The study revealed that the methanol extracts of $A$. angustissima pods depicted 
significant antioxidant activity by DPPH and ABTS with the $\mathrm{IC}_{50}$ values ranging from $349.1-364.6 \mu \mathrm{g} / \mathrm{mL}$ and 110.3-149.5 $\mu \mathrm{g} / \mathrm{mL}$, respectively, which was higher than the two controls; gallic acid $(33.1 \mu \mathrm{g} / \mathrm{mL}$ for DPPH and $15.39 \mu \mathrm{g} / \mathrm{mL}$ for ABTS) and Trolox $(104.2 \mu \mathrm{g} / \mathrm{mL}$ for DPPH and $43.90 \mu \mathrm{g} / \mathrm{mL}$ for ABTS). The methanol extracts of the plant has a reducing ability ranging from 2.05- $2.77 \mathrm{mmol}$. Furthermore, the study showed that the extracts possessed medium antimutagenic activity at concentrations below $0.625 \mathrm{mg} / \mathrm{mL}$, however, at the concentrations of $0.625-5 \mathrm{mg} / \mathrm{mL}$, a strong antimutagenic activity was observed. In addition, the extracts also displayed fungistatic activity against Fusarium oxysporum, Rhizoctonia solani and Phytophtora capsici [28].

\section{Other Uses}

In Mexico, the bitter astringent bark of $A$. angustissima is used for precipitating mucilaginous matter and inducing fermentation in the making of alcoholic drinks [6]. The indigenous people of Chiapas and Mesoamerica use $A$. angustissima in their culture, medicine and arts [29]. Llaveia mexicanorum, a native Homoeptera scale insect, uses the shrubs as their hosts [29], and the insect is then used by the indigenous people of Chiapas and Mesoamerica to produce a fat for traditional lacquer wood handcrafts [30]. The leguminous shrub accumulates quality tannins in its bark, which is traditionally extracted to tan leather in the leather industry [31, 32]. Correspondingly, fodder trees also provide the farmers with other useful products and services such as firewood, timber, and bee forage [33].

Research indicated that $A$. angustissima respond well to coppicing and is characterized by high leaf yield with fodder potential as well as for biomass transfer than any other shrub legumes, such as Leucaena leucocephala (Lam.) de Wit, Gliricidia sepium (Jacq.) Kunth ex Walp, Cajanus cajan (L.) Mill, and Sesbania sesban Linn [34, 35]. It has been reported that $A$. angustissima is used as a source of supplementary to native pasture hay as it provides protein, vitamins, and minerals in long dry seasons [36-39]. A. angustissima has great nutritional potential but is limited by the presence of antinutritional compounds such as tannins content of $6 \%$ DM $[40,41]$.

A gradual decline of soil fertility is a concomitant issue in the sub-Saharan region [42] and is increasingly recognized as a fundamental biophysical cause of declining food security among small-farm households in sub-Saharan Africa [43-45]. Agroforestry has emerged as an alternative strategy to replenish soil fertility with the valuable $A$. angustissima forming a symbiotic association with soil Rhizobium to fix atmospheric nitrogen which can be made available to crop by pruning the leaves and twigs and incorporating these in the soil to enhance crop yield [46]. Ensifer mexicanus sp. nov. bacteria are reportedly responsible for nodulating $A$. angustissima species in Mexico [47] and the nodulation is also improved with fertilization [7]. A. angustissima trees can be fitted into production systems as rotation crops, intercrops, and relay crops, or grown outside the main fields and used for biomass transfer $[46,48,49]$. A. angustissima is one of the important agroforestry tree species whose biomass can be used for soil improvement in crop production [45].

\section{CONCLUSIONS}

The shrub has ecological, medical, and industrial potential. With most communities in sub-Saharan Africa heavily reliant on the local vegetation for traditional medicine, the leguminous shrub is frequently used in contemporary treatments for wound healing, cures toothache, rheumatism, skin lesions, bloody diarrhea and mucoid diarrhea. It is also a good source of phenolic compounds and displays a mild antimicrobial effect and has the ability to inhibit growth in malignant tumors as well as anticancer properties. Extensive research revealed that $A$. angustissima is characterized by high leaf yield for biomass transfer and livestock feed and also provide other useful products and services such as firewood, timber, and bee forage while restoring soil fertility and preventing soil erosion. The scientific evidence of $A$. angustissima phytochemistry and pharmacological properties indicate the therapeutic potential of the plant. However, there is a need to assess the efficacy and safety of the plant as herbal medicine through ethnopharmacological studies emphasizing clinical and toxicological evaluations.

\section{CONFLICT OF INTEREST STATEMENT}

The authors have not declared any conflict of interest.

\section{FUNDING}

None.

\section{ACKNOWLEDGEMENTS}

The authors would like to express their gratitude to the Govan Mbeki Research and Development Centre 
(GMRDC), University of Fort Hare for financial support to conduct this research.

\section{REFERENCES}

[1] Rico Arce ML, Bachman S. A taxonomic revision of Acaciella (Leguminosae, Mimosoideae). Analesdel Jardín Botánico de Madrid 2006; 63(2): 189-244.

https://doi.org/10.3989/ajbm.2006.v63.i2.7

[2] Roshetko JM. Agroforestry species and technology: A compilation of the highlights and factsheets published by NFTA and FACT Net 1985-1999. Taiwan: Taiwan Forestry Research Institute and Council of Agriculture 2001.

[3] Csurhes $S$, Naïve $S$. Weed risk assessment. White ball Acacia. Acaciella angustissima (syn. Acacia angustissima, Acacia boliviana), Australia: The State of Queensland, Department of Employment, Economic Development and Innovation 2009; 28.

[4] Raine NE, Pierson AS, Stone GN. Plant-pollinator interactions in a Mexican Acacia community. Arthropod-Plant Interactions 2007; 1(2): 101-117 https://doi.org/10.1007/s11829-007-9010-7

[5] Hossan, Shahadat, Bipasha, A, Shahnawaz S, Masud K, Rownak J, Mohammed R. Traditional use of medicinal plants in Bangladesh to treat urinary tract infections and sexually transmitted diseases. Ethnobotany Research and Applications, [S.I.], 2010; 8: 061-074, Apr. 2010. ISSN 15473465.

https://doi.org/10.17348/era.8.0.61-74

[6] Rinne EM. Water and healing - Experiences from the traditional healers in Ile-Ife, Nigeria. Nordic Journal of African Studies 2001; 10(1): 41-65.

[7] Maroyi A. An ethnobotanical survey of medicinal plants used by the people in Nhema communal area, Zimbabwe. Journal of Ethnopharmacology 2011; 11: 347-354. https://doi.org/10.1016/.jep.2011.05.003

[8] Cook BG, Pengelly BC, Brown SD, Donnelly JL, Eagles DA, Franco MA, Hanson J, Partridge IJ, Peter M, Schultze-Kraft R. Tropical Forages: an interactive selection tool. Brisbane, Australia: CSIRO, DPI\&F, CIAT, ILRI 2005

[9] Ncube S, Hamudikuwanda H, Saidi PT. The Potential of Acacia angustissima Leaf Meal as a Supplementary Feed Source in Broiler Finisher Diets. International Journal of Poultry Science 2012; 11(1): 55-60.

https://doi.org/10.3923/ijps.2012.55.60

[10] Orwa C, Mutua A, Kindt R, Jamnadass R, Simons A.. Agroforestrey Database: $A$ tree reference and selection guide version 4.0. World Agroforestry Centre 2009.

[11] Odenyo AA, Osuji PO, Reed JD, Smith AH, Mackie RI, McSweeney CS, Hanson J. Acacia angustissima: Its antinutrients constituents, toxicity and possible mechanisms to alleviate the toxicity- a short review. Agroforestry Systems (The Netherlands) 2003; 54(3): 141-147. https://doi.org/10.1023/A:1026360912944

[12] Terrones-Rincon R. Arbustivasnativas de uso multiple. Agricultural and Livestock Research (INIFAP), National Institute of Forestry 2006; pp. 145-184.

[13] Dzowela BH. Acacia angustissima: A Central American tree that's going places. Agroforestry Today 1994; 6(3): 13-14.

[14] Preece D, Brook R. Acacia angustissima-a promising species for agroforestry? FACT Sheet 99-01. A quick guide to multipurpose trees from around the world. FACT Net Winrock International Arkansas 1999

[15] Dzowela BH, Hove L, Maasdorp BV, Mafongoya PL. Recent work on the establishment, production and utilization of multipurpose trees as a feed resource in Zimbabwe. In: Animal Feed Science and Technology, 69(1/3) [ed. by Acamovic, T.IStewart, C.S.ITopps, J.H.] 1997; 1-15. https://doi.org/10.1016/S0377-8401(97)81618-5
Brook RM. Early results from an alley cropping experiment in the humid lowlands of Papua New Guinea. Nitrogen Fixing Tree Research Reports 1992; 10: 73-76.

Hove L, Franzel S, Moyo PS. Farmer Experiences in the production and utilization of fodder trees In Zimbabwe: Constaints and Opportunities for Increased Adoption. Tropical Grasslands 2003; 37: 279-283.

[18] Böhringer A. Facilitating the wider use of Agroforestry for development in southern Africa. Development in Practice 2001; 11(4): 434-448. https://doi.org/10.1080/09614520120066729

[19] Rincón-Rosales R, Gutiérrez-Miceli F. [English title not available]. (Características biológicas de Acaciella angustissima (Mill.) Britton \& Rose ensu habitat natural y evaluación de supotencial cortical en Chiapas, México.) Agrociencia 2008; 42: 129-137.

[20] Veloz-García R, Marín-Martínez R, Veloz-Rodríguez F, Rodríguez-Guerra R, Torres-Pacheco I, Gonzalez-Chavira MM, Anaya-López JL, Guevara-Olvera L, Feregrino-Pérez AA, Loarca-Pina G, Guevara-González RG. Antimicrobial activities of cascalote (Caesalpinia cacalaco) phenolicscontaining extract against fungus Colletotrichum lindemuthianum. Industrial Crops and Production 2010; 31 134-138. https://doi.org/10.1016/j.indcrop.2009.09.013

[21] Feregrino-Pérez AA, Torres-Pacheco I, Vargas-Hernández M, Munguía-Fragozo P, Loarca-Pina V, Mendoza-Díaz GF, Ocampo-Velázquez SO, Rico-García RV, Guevara-Gónzalez ERG. Antioxidant and antimutagenic activities of Acacia pennatula pods. Journal of Scientific and Industrial Research (JSIR) 2011; 70: 859-864

[22] Marín-Martínez R, Veloz-García R, Veloz-Rodríguez $R$ Guzmán-Maldonado S, Loarca-Pina G, Cardador-Martínez A, Guevara-Olvera L, Miranda-López R, Torres-Pacheco I, Pérez C, Herrera-Hernández G, Villasenor-Ortega $F$, González-Chavira M, Guevara-González R. Antimutagenic and antioxidant activities of quebracho phenolics (Schinopsis balansae) recovered from tannery wastewaters. Bioresour Technol 2009; 100: 434-439. https://doi.org/10.1016/j.biortech.2008.05.029

[23] Hoffmann JJ, Timmermann BN, McLaughlin SP, Punnapayak $\mathrm{H}$. Potential antimicrobial activity of plants from the southwestern United States. International Journal of Pharmacognosy 1993; 31(2): 101-115. https://doi.org/10.3109/13880209309082926

[24] Alonso-Castro AJ, Villarreal ML, Salazar-Olivo LA, GomezSanchez M, Dominguez F, Garcia-Carranca A. Mexican medicinal plants used for cancer treatment: pharmacological, phytochemical and ethnobotanical studies. Journal of Ethnopharmacology 2011; 133(3): 945-72. https://doi.org/10.1016/i.jep.2010.11.055

[25] Estrada-Muñiz E, Guerrero-Palomo G, Vega L. Natura products: New anti-cancer agents derived from plants. Toxicology 2006; 1.

[26] Rodríguez-Méndez AJ, Carmen-Sandoval W, Lomas-Soria C, Guevara-González RG, Reynoso-Camacho R, VillagranHerrera ME, Salazar-Olivo L, Torres-Pacheco I, FeregrinoPérez AA. Timbe (Acaciella angustissima) Pods Extracts Reduce the Levels of Glucose, Insulin and Improved Physiological Parameters, Hypolipidemic Effect, Oxidative Stress and Renal Damage in Streptozotocin-Induced Diabetic Rats. Molecules 2018; 23(11): 2812 https://doi.org/10.3390/molecules23112812

[27] Alonso-herrada J, Rico-reséndiz F, Campos-guillén J. Establishment of in vitro regeneration system for Acaciella angustissima (Timbe ) a shrubby plant endemic of México for the production of phenolic compounds. Ind Crop Prod 2016; 86: 49-57. https://doi.org/10.1016/j.indcrop.2016.03.040

[28] Vargas-Hernández M, Munguía-Fragozo PV, CruzHernández A, Guerrero BZ, Gonzalez-Chavira MM, 
Feregrino-Pérez AA, Mendoza-Díaz So, Loarca-Piña G, Torres-Pacheco I, Hernández-Salazar M, Guevara-Gonzalez RG. Bioactivity and gene expression studies of an arbustive Mexican specie Acaciella angustissima (Timbe). Industrial Crops and Products 2014; 52: 649-655. https://doi.org/10.1016/j.indcrop.2013.11.018

[29] Williams ML, MacVean CM. Ethmcoccidiby: Use of the giant margarodid, Llaveia spp (Homoeptera: Coccoidea: Margarodidae), by indigenous peoples of Mesoamerica in their culture, medicine and arts. Israel Journal of Entomology 1995; 29: 147-148.

[30] Grillasca MMA. Lacachiapaneca: Ensayo de una singular aventura. Consgo Estatal para las Cultural y las Artes de Chiapas. Comeculta, Mexico 2007; p. 127.

[31] Rincón RR, Culebro NR, Miceli FAG, Dendooven L. Scarification of seeds of Acacia angustissima (Mill.) Kuntze and its effect on germination. Seed Science Technology 2003; 31: 301-307.

https://doi.org/10.15258/sst.2003.31.2.07

[32] Hussein SA. Utilization of Tannins Extract of Acacia seyal Bark (Taleh) in Tannage of Leather. Journal of Chemical Engineering Process Technology 2017; 8: 334. https://doi.org/10.4172/2157-7048.1000334

[33] Franzel S, Carsan S, Lukuyu B, Sinja J, Wambugu C. Fodder trees for improving livestock productivity and smallholder livelihoods in Africa. Current opinion in environmental sustainability 2014; 6: 98-103. https://doi.org/10.1016/j.cosust.2013.11.008

[34] Gutteridge RC. Other species of multipurpose forage tree legume. In: Gutteridge RC, Shelton HM, Eds., Forage tree legumes in tropical agriculture. CAB International, Wallingford, UK 1994; pp. 98-99.

[35] Matimati I, Maasdorp BV, Hove L. On-farm productivity of Acacia angustissima, Calliandra calothyrsus and Leucaena leucocephala in a subhumid area in Zimbabwe. Afr J Range For Sci 2009; 26(2): 75-80. https://doi.org/10.2989/AJRFS.2009.26.2.4.847

[36] Osuji PO, Fernández-rivera $S$, Odenyo AA. Improving fibre utilization and protein supply in animals fed poor quality roughages: ILRI nutrition research and plans. In: Wallace, R.J., Lahlou-Kassi, A. (eds.), Rumen Ecology Research Planning. International Livestock Research Institute (ILRI): Nairobi, Kenya 1995; 1-22.

[37] Masama E, Topps JH, Ngongoni NT, Maasdorp BV. Effects of supplementation with foliage from the tree legumes Acacia angustissima, Cajanus cajan, Calliandra calothyrsus and Leucaena leucocephala on feed intake, digestibility and nitrogen metabolism of sheep given maize stover ad libitum. Animal Feed Science and Technology 1997; 69: 233240. https://doi.org/10.1016/S0377-8401(97)81638-0

[38] Hove L, Topps JH, Sibanda S, Ndlovu LR. Nutrient intake and utilisation by goats fed dried leaves of the shrub legumes Acacia angustissima, Calliandra calothyrsus and Leucaena leucocephala as supplements to native pasture hay 2001. https://doi.org/10.1016/S0377-8401(01)00233-4
[39] McSweeney CS, Collins EMC, Blackall LL, Seawright AA. A review of anti-nutritive factors limiting potential use of Acacia angustissimaas a ruminant feed. Animal Feed Science and Technology 2008; 147(1/3): 158-171.

https://doi.org/10.1016/j.anifeedsci.2007.09.015

[40] Smith AH, Odenyo AA, Osuji PO, Wallig MA, Kandil FE, Seigler DS, Mackie RI. Evaluation of toxicity of Acacia angustissima in a rat bioassay. Animal Feed Science and Technology 2001; 91: 41-57.

https://doi.org/10.1016/S0377-8401(01)00230-9

[41] Smith AH, Wallig MA, Seigler DS, Odenyo AA, Mcsweeney CS, Mackie RI. Amelioration of toxic effect of Acacia angustissima with polyethylene glycol in rats. Anim. Feed Sci Tech 2003; 106: 165-174. https://doi.org/10.1016/S0377-8401(03)00009-9

[42] Vanlauwe B, Wendt J, Giller KE, Corbeels M, Gerard B, Nolte C. A fourth principle is required to define 1 Conservation Agriculture in sub-Saharan Africa: the appropriate use of fertilizer to enhance crop productivity. Field Crop Res 2014b; 155: 10-13.

https://doi.org/10.1016/j.fcr.2013.10.002

[43] Sanchez PA, Palm CA, Scott LT, Cuevas E, Lal R. Organic input management in tropical agro ecosystems. In: Coleman, D.C., Oades, J.M. Uehar, G. Eds. Dynamics of soil organic matter in tropical ecosystems. Nif TAL Project. University of Hawaii. Hoduln, Hi 1997; pp. 125-152.

[44] Place F, Franzel S, DeWolf J, Rommelse R, Kwesiga F, Niang A, Jama B. Agroforestry for soil fertility replenishment: Evidence on adoption processes in Kenya and Zambia. In: Barrett, C.B., Place, F., Aboud, A.A. (Eds.), Natural Resources Management in African Agriculture: Understanding and Improving Current Practices. CAB International, Wallingford, UK 2002; pp. 155-168. https://doi.org/10.1079/9780851995847.0155

[45] Musara C, Chitamba J. Growth rate and yield of Brassica napus in response to Acacia angustissima leaf biomass application. JAPS, Journal of Animal and Plant Sciences 2015; 25(2): 510-518.

[46] Bala A, Giller KE. Relationships between Rhizobial Diversity and Host Legume Nodulation and Nitrogen Fixation in Tropical Ecosystems. Nutrient Cycling in Agro Ecosystems 2006; 76: 319-330. https://doi.org/10.1007/s10705-005-2003-y

[47] Lloret L, Ormeño-Orrillo E, Rincón R, Martínez-Romero J, Rogel-Hernández MA, Martínez-Romero E. Ensifer mexicanus sp. nov. A new species nodulating Acacia angustissima (Mill.) Kuntze in Mexico. Systematic and Applied Microbiology 2007; 30(4): 280-290. https://doi.org/10.1016/j.syapm.2006.12.002

[48] Matarirano L. An article: Avoid fertilizers; try legumes. New Farmer 2003; 4(8): 25-31.

[49] Gindaba J, Rozanov AB, Negash L. Trees on farms and their contribution to soil fertility parameters in Badessa, eastern Ethiopia. Article in Biology and Fertility of Soils 2005; 42(1): 66-71.

https://doi.org/10.1007/s00374-005-0859-2

Received on 05-09-2020

\section{DOI: https://doi.org/10.29169/1927-5951.2020.10.06.2}

(C) 2020 Musara and Aladejana; Licensee SET Publisher.

This is an open access article licensed under the terms of the Creative Commons Attribution Non-Commercial License (http://creativecommons.org/licenses/by-nc/3.0/) which permits unrestricted, non-commercial use, distribution and reproduction in any medium, provided the work is properly cited. 